ks. Dariusz Szczepan Skowron SDB

Międzyuczelniany Instytut Muzyki Kościelnej w Krakowie

\title{
Sprawozdanie z dziatalności Koła Naukowego Congaudeant Międzyuczelnianego Instytutu Muzyki Kościelnej w roku akademickim 2017-2018
}

Inauguracja Roku Akademickiego 2017/2018

Paźclziernik 2017

Po długim wakacyjnym odpoczynku dnia 2 października 2017 roku przyszedł czas powrotu do szkolnej ławy. Rozpoczęcie roku akademickiego jest dobrym momentem na spotkanie się z pedagogami, ustalenie i korygowanie indywidualnych zajęć, czytanie i zapoznawanie się z nowymi ministerialnymi wytycznymi, a także umiłowanymi sylabusami. Jest to również czas powitania nowych studentów, którzy po raz pierwszy weszli w struktury Międzyuczelnianego Instytutu Muzyki Kościelnej.

Wraz z pierwszym dzwonkiem działalność wznawia Naukowe Koło Congaudeant, którego opiekunem jest w dalszym ciągu s. dr hab. Susi Ferfoglia. Podczas inaugurującego spotkania został wybrany nowy zarząd Koła. Przedstawia się on następująco: przewodniczący - Michał Piechnik, zastępca - Marcin Miotelka, sekretarz - s. Sylwia Marciniak. Działalność studencka żywo przedstawia się podczas koncertów, konkursów i festiwali.

\section{Dni Muzyki Kościelnej}

Listopad 2016

Tradycją lat minionych listopad to czas wzmożonych przygotowań do Dni Muzyki Kościelnej. Kolejne, trzynaste, odbyły się w dniach 17-22 listopada 2017 roku pod patronatem abpa Marka Jędraszewskiego metropolity krakowskiego. Dni te rozpoczęte zostały X Krakowskim Konkursem Młodych Organistów. 
Dzień 19 listopada był obfity w koncerty. Pierwszy odbył się w kościele Świętego Jana Chrzciciela w Krakowie o godz. 14.30. Był to koncert organowy absolwentów Międzyuczelnianego Instytutu Muzyki Kościelnej w Krakowie. Wystąili: Maria Cebula, Józef Łukasz, Łukasz Sandera. W repertuarze można było usłyszeć m.in. utwory: Jana Sebastian Bacha - Fantazja G-dur BWV 572, Allein Gott in der Höh sei Ehr BWV 662 (wyk. Józef Łukasz); Charles'a-Marie Widora - Méditation op. 13, Maurice'a Durufé - Choral varié (Veni Creator) op. 4 (wyk. Maria Cebula).

Drugi koncert odbył się o godz. 16.00 w kościele Matki Bożej Ostrobramskiej na nowo poświęconych organach firmy D. Zych. Był to koncert w wykonaniu zespołu Flores Rosarum oraz koncert organowy w wykonaniu s. Susi Ferfogli. Można było w nim usłyszeć m.in. utwory: Arvo Pärta - Vater unser - na głos dziecięcy i organy, Charles'a-Marie Widora - Symphonie gothique op. 70, I i II cz. i ostatnią wariację oraz Flora Peetersa - Toccata n/t Ave Maris Stella op. 28.

Trzeci i ostatni koncert tego dnia miał miejsce w kościele Najświętszego Salwatora w Krakowie o godz. 19.30. Był to koncert organowo-chóralny. Wykonawcami koncertu byli: Maciej Banek - organy, chór chłopięcy Pueri Cantores Sancti Joseph, Agata Nawrot - dyrygent. Można było usłyszeć m.in. następujące utwory: Feliksa Rączkowskiego - Bogurodzica, Anonima (XIII wiek), Bogurodzica, Missa XI (Orbis Factor), Jana Sebastiana Bacha - Fantazja G-dur BWV 572, Léo Delibesa Messe brève.

20 i 22 listopada to dni konwersatoriów i wykładów. W auli Akademii Muzycznej odbyły się konwersatorium i wykład na temat interpretacji muzyki organowej. Przeprowadzit je prof. Jon Laukvik.

22 Listopada w auli „Florianka” odbyła się Międzynarodowa Konferencja Naukowa Musica sacra - instrumentum laudis. 50 lat w stużbie muzyki kościelnej. Instrukcja wykonawcza Soboru Watykańskiego II „Musicam sacram” (1967-2017). Słowo wprowadzające wygłosił JM prof. dr hab. Stanisław Krawczyński, rektor Akademii Muzycznej w Krakowie. Program wykładów przedstawiał się następująco:

Prowadzenie:

ks. dr hab. Robert Tyrała prof. UPJPII (Uniwersytet Papieski Jana Pawła II, Akademia Muzyczna, Kraków)

Wykłady:

1. Mons. prof. Vincenzo de Gregorio, Papieski Instytut Muzyki Kościelnej, Watykan, Chiesa, Arte e Musica: un'esperienza di ricerca e di scoperta di sempre nuovi orizzonti (Kościót, sztuka i muzyka: doświadczenie poszukiwań i odnajdywania zawsze nowych horyzontów) 
2. Dr hab. Michał Sławecki, Uniwersytet Muzyczny, Warszawa, Śpiew gregoriański w liturgii po Soborze Watykańskim II - dokumenty, ludzie, fakty, praktyka

3. Don Gilberto Sessantini Bergamo, Włochy, Il ministero dell'organo e dell’organista in Musicam sacram. Bilanci e prospettive (Postuga organów i organisty w „Musicam sacram". Ocena i perspektywy)

4. Ks. dr Marius Linnerborn, Instytutu Liturgiczny, Trier, Niemcy, Die Aufgaben der Chöre in der Liturgie heute (Zadanie chórów w liturgii dzisiejszych czasów)

5. Ks. dr Wojciech Kałamarz CM, Kraków, Śpiew wiernych w liturgii w świetle watykańskiej instrukcji „Musicam sacram”

$\mathrm{Na}$ zakończenie konferencji nastąpiło wręczenie czasopisma „Pro Musica Sacra” 15 (2017) dedykowanego ks. prof. dr hab. Janowi Józefowi Janickiemu z okazji 70 . rocznicy urodzin.

Zakończenie obchodów XIII Dni Muzyki Kościelnej odbyło się podczas uroczystych nieszporów w kościele Świętego Marka celebrowanych przez ks. Roberta Tyrałę.

\section{Sądecka Akademia organowa}

\section{7-8 listopada}

Sądecka Akademia Organowa, która została zainaugurowana 1 kwietnia 2017 roku, scala działania artystyczne, naukowe i edukacyjne związane z szeroko pojętą sztuką gry organowej. Inicjatorem i dyrektorem artystycznym tego przedsięwzięcia jest prof. Ireneusz Wyrwa.

Korzystając z wszechstronnej działalności tego ośrodka, dniach 7-8 listopada studenci Międzyuczelnianego Instytutu Muzyki Kościelnej wzięli udział w mistrzowskim kursie interpretacji Niemiecka muzyka romantyczna na organach $w$ kościele Świętego Kazimierza w Nowym Sączu. Kurs prowadzony był przez prof. Martina Schmedinga, renomowanego artystę i cenionego pedagoga, który był zarazem gwarantem owocnej pracy podczas kursu.

\section{Inicjatywy}

\section{Sztuka rejestracji organowej}

Rejestracja literatury organowej to nie „wyciaganie kołków”, wciskanie guzików i kręcenie wałkiem czy żaluzją. To żmudne dobieranie barw, brzmień, kolorów, alikwot i głosów. Inicjatywa Sztuka rejestracji organowej powstała przy 
udziale s. Susi Ferfoglii oraz Filipa Presseisena - pedagogów Międzyuczelnianego Instytutu Muzyki Kościelnej, którzy dostrzegli potrzebę zdobywania tej umiejętności i wiedzy. Prowadzącym spotkania jest Filip Presseisen.

Pierwsze spotkanie odbyło się w listopadzie i miało charakter wprowadzający, czysto teoretyczny. Poprzez metody, zapis, stylistykę, brzmienie, źródła historyczne i inne procesy rejestracji można było utwierdzić się w przekonaniu, że rejestracja organowa to rzeczywiście sztuka.

Kolejne spotkania - już praktyczne - odbywały się na różnych wartościowych i specyficznych instrumentach Kościoła w Krakowie i nie tylko.

\section{Organmistrz w praktyce}

Z inicjatywy opiekun koła s. Susi Ferfoglii zorganizowany został wyjazd do Zakładu Organmistrzowskiego Ars Organum w Sulechowie prowadzonego przez Adama Olejnika. Wyjazd odbył się w dniach 8-10 marca i był połączony z sympozjum naukowym Convenium musicae sacrae dedicatum.

Pan Olejnik, otwierając drzwi swojego zakładu, przybliżył działalność, charakterystykę i specyfikę pracy. Można było zobaczyć kościoły, w których firma Ars Organum budowała bądź restaurowała organy. Był to m.in. kościół Najświętszej Maryi Panny w Klępsku. Uczestnicy zwiedzali organy Samuela Ludwiga Hartiga z 1822 roku. Pan Olejnik przekazywał ciekawostki związane z budową instrumentu, charakterystyką brzmienia organów, problematyką konserwatorską związaną z restauracją instrumentu w latach 2007-2009.

\section{Wokót muzyki liturgicznej - konferencja naukowa}

\section{8 listopada 2017 roku}

Kontynuując wykładnie nauki Kościoła katolickiego dotyczącą muzyki kościelnej, przekazaną podczas warsztatów i konferencji w czasie XIII Dni Muzyki Kościelnej, 28 listopada grupa studentów wybrała się po kolejną dawkę wiedzy. Tym razem do Akademii Muzycznej w Katowicach, gdzie odbyła się konferencja naukowa. Związana była ona z obchodami Dnia Muzyki Liturgicznej Archidiecezji Katowickiej. Wpisywała się ten dzień w treść 33. niedzieli zwykłej i był okazją, by traktować go jako czas dziękczynienia za muzyczne dziedzictwo Kościoła lokalnego.

Jeden z wykładów w czasie konferencji prowadził nasz wykładowca, ks. prof. dr hab. Andrzej Zając. Wygłosił on wykład pt.: Wykonawcy wokalnej muzyki liturgicznej (kantor, psatterzysta, schola, chór). 


\section{Wielki jubileusz - jubileusz 130-lecia Akademii Muzycznej w Kra- kowie}

\section{4-25 lutego 2018 roku}

Rok 2018 to wielkie wydarzenie dla ośrodka muzycznego, jakim jest akademia. 130 lat temu, w 1888 roku Konserwatorium Towarzystwa Muzycznego w Krakowie uzyskało decyzją Ministra Wyznań i Oświecenia Publicznego CK Austrii status uczelni wyższej. Dlatego też data ta wyznacza czas rozpoczęcia działalności uczelni.

Uroczystości jubileuszu wyznaczone zostały na dni 24-25 listopada. Pierwszego dnia świętowania w bazylice mariackiej o godz. 18.30 odbyła się Eucharystia, na której śpiewał chór Międzyuczelnianego Instytutu Muzyki Kościelnej. Msza święta sprawowana była w intencji tych, którzy współtworzą Akademię, oraz tych, którzy tworzyli ją, lecz już odeszli. Główne uroczystości jubileuszowe połączone z koncertem odbyły się w sali Filharmonii Krakowskiej.

Podczas koncertu można było usłyszeć Magnificat Mikołaja Zieleńskiego, którego renesansowo-barokowe dzieła znajdują się m.in. w krakowskich bibliotekach, a także uwerturę charakterystyczną - W Tatrach - inicjatora i pierwszego dyrektora konserwatorium Władysława Żeleńskiego. Koncert zakończył utwór Polymorphia na 48 instrumentów smyczkowych Krzysztofa Pendereckiego, absolwenta krakowskiej uczelni, a później i jej rektora (w latach 1972-1987).

\section{Koncerty}

Muzyczna pasja i rozwijanie talentu pomagają w nabieraniu przekonania, iż tego, co robimy, nie robimy li tylko dla siebie, lecz pomagamy innym w przeżywaniu tego, co święte. Wiele koncertów, które przeżywamy i którymi się dzielimy, zasługuje na uwagę.

Jednym z nich - już od kilku lat - jest droga krzyżowa z muzyką, która gromadzi wielu wiernych przeżywających w czasie Wielkiego Postu Pasje Jezusa Chrystusa. Tegoroczna odbyła się 23 marca 2018 roku w Kościele Ojców Pijarów Matki Bożej Ostrobramskiej. Rozważania męki Pańskiej do tekstu Paula Claudela mistycznie korespondowała z muzyką Marcela Dupré Le Chemin de la Croix op. 29. Wykonawcami byli pedagodzy i studenci Międzyuczelnianego Instytutu Muzyki Kościelnej.

Kolejnym niecodziennym koncertem był koncert Resurrexit, nawiązujący do radości Zmartwychwstania. Była to inicjatywa studentów II roku Międzyuczelnianego Instytutu Muzyki Kościelnej, którzy wykonali utwory z XVI-wiecznych 
polskich tabulatur organowych na przemian ze śpiewem gregoriańskim z polskich źródeł liturgicznych XVI i XVII wieku. Koncert odbył się 23 kwietnia 2018 roku w kościele Świętego Krzyża w Krakowie.

Majowy koncert zabrzmiał w Kościele Ojców Bernardynów Świętego Bernarda ze Sieny. Odbył się on 18 maja 2018 roku. Koncert zagrali: Damian Sowa - tegoroczny dyplomant, wykonując m.in. utwory Jana Sebastiana Bacha - Preludium i Fugę c-moll BWV 546, Fantazję G-dur BWV 572, oraz Anna Chruściel i Paweł Grabczyński, którzy zinterpretowali utwory na cztery ręce Gustava A. Markela - Sonatę d-moll op. 30 i utwór Wolfganga Amadeusza Mozarta - Fantazjef-moll KV 608.

Zakończenie roku akademickiego związane jest z letnią sesją egzaminacyjną, która mobilizuje studentów do wzmożonego intelektualnego wysiłku, by pozytywnie zakończyć rok. Związane jest ono również z dyplomami i egzaminami licencjackimi i magisterskimi, które - miejmy nadzieję - dobrze się skończą. 